\title{
PENGEMBANGAN MANAJEMEN DATA DAN INFORMASI MENGGUNAKAN ANALISIS SOFT SYSTEM METHODOLOGYDI UNIVERSITAS ADVENT INDONESIA
}

\author{
Thalia Dorkas Septiana*1, Raymond Maulany ${ }^{2}$ \\ 1,2 Fakultas Teknologi Informasi, Universitas Advent Indonesia \\ e-mail: *1thalia.limbong.tl@gmail.com, 2raymond@unai.edu
}

\begin{abstract}
Abstrak
Manajemen data dan informasi merupakan bagian penting dalam Lembaga Pendidikan seperti kampus atau Universitas. Manajemen data dan informasi pada Universitas Advent dinilai mengalami hambatan dalam menerima dan mengirim data informasi pada website kampus. Maka dari itu metode SSM dinilai sebagai metode yang paling cocok dalam meningkatkan pengembangan manajemen data dan informasi pada Universitas Advent Indonesia. Soft system methodology dianggap sebagai metodologi yang berbasis operasional manajemen data di Universitas Advent Indonesia. Soft system methodologymerupakan sistem metodologi yang digunakan dengan maksud untuk menjelaskan tujuan dari suatu lembaga dan merancang sebuah sistem atau aktivitas dalam mencapai tujuan bersama. Penelitian ini bertujuan untuk memperjelas dan memaparkan tentang bagaimana pengembangan manajemen data dan informasi menggunakan metode analisis soft system methodology. Penelitian ini bersifat kualitatif deskriptif, serta menggunakan teknik CATWOE yang merupakan salah satu teknik dalam tahapan SSM terutama dalam tahap pengungkapan situasi masalah secara terstruktur. Berdasarkan hasil penelitian dapat disimpulkan bahwa penggunaan metodologi soft system dalam pengelolaan data dan informasi merupakan salah satu metode alternatif yang tepat dalam menyelesaikan tantangan dan permasalahan yang dihadapi oleh mahasiswa Universitas Advent Indonesia untuk memudahkan pendaftaran dan transfer informasi di asrama.
\end{abstract}

Kata Kunci: Manajemen data, SSM, Sistem Informasi

\section{DATA AND INFORMATION MANAGEMENT DEVELOPMENT USING SOFT SYSTEM ANAL YSIS METHODOLOGY AT ADVENT INDONESIA UNIVERSITY}

\begin{abstract}
Data and information management is an important part of educational institutions such as campuses or universities. Data and information management at Adventist University is considered to have obstacles in receiving and sending information data on campus websites. Therefore, the SSM method is considered as the most suitable method in improving the development of data and information management at Advent Indonesia University. Soft system methodology is considered as a methodology based on operational data management at Advent Indonesia University. Soft system methodology is a system methodology that is used with the intention of explaining the goals of an institution and designing a system or activity to achieve common goals. This study aims to clarify and explain how the development of data and information management using soft system methodology analysis. This research is descriptive qualitative in nature, and uses the CATWOE technique which is one of the techniques in the SSM stage, especially in the structured disclosure stage of the problem situation. Based on the research results, it can be concluded that the use of soft system methodology in data and information management is one of the appropriate
\end{abstract}


alternative methods in solving the challenges and problems faced by students of the Adventist University of Indonesia to facilitate registration and transfer of information in dormitories.

Keywords: Data management, SSM, Information Systems

\section{Pendahuluan}

\section{Latar Belakang}

Sistem adalah sekumpulan variabel berkaitan satu dengan yang lain dan saling mempengaruhi dalam melakukan suatu kegiatan untuk mencapai suatu tujuan [1]. Sistem kerja merupakan suatu bentuk kesatuan yang di dalamnya terdiri dari unsur-unsur yang berasal dari manusia, bahan, perlengkapan, metode kerja, dan lingkungan kerja untuk dapat mencapai suatu tujuan tertentu [2]. Sistem kerja pada zaman sekarang keseluruhannya telah berbasis teknologi. Munculnya Sistem teknologi telah menjadi salah satu alternatif yang digunakan oleh manusia dalam membantu menyelesaikan pekerjaannya. Berpikir serba sistem artinya kita berpandangan bahwa sistem sebagai bidang yang dinilai mempunyai suatu transdisiplin yang dapat memproses reduksi dalam memecahkan masalah akibat adanya perubahan pada teknologi dan faktor lainnya.

Selain untuk proses pembelajaran, teknologi dalam dunia Pendidikan juga memiliki fungsi penting sebagai pengelola dalam manajemen data dan informasi yang digunakan oleh beberapa Lembaga Pendidikan di Indonesia. Universitas Advent Indonesia merupakan salah satu dari sekian banyak Lembaga Pendidikan yang menggunakan soft system methodology dalam operasionalnya. Universitas merupakan sebuah Lembaga Pendidikan, yang di dalamnya terdapat banyak organisasi, dan berbagai macam departemen yang artinya di sebuah Universitas pasti memiliki banyak jenis data yang perlu di atur, agar semua data tersebut dapat terorganisir dengan baik. Manajemen data dan informasi pada Universitas Advent dinilai mengalami hambatan dalam menerima dan mengirim data informasi pada website kampus. Maka dari itu, sangat dibutuhkan pengembangan manajemen data yang baik. Memandang suatu sistem dalam organisasi, sistem secara keseluruhan dinilai lebih besar cakupannya dibanding jumlah dari bagianbagiannya. Sifat-sifat pada keseluruhan sistem tidak dapat diterangkan seluruhnya dalam terminologi sifat unsur-unsurnya. Prinsip sistem juga menyiratkan bahwa dalam mengembangkan aplikasi harus dilakukan pengembangan sistem organisasi secara keseluruhan dari pada mengembangkan dengan fungsi-fungsi secara terpisah.

Manajemen data dan informasi adalah sebuah cara dalam mengelola data dan informasi dengan organisasi dan strategi terutama dalam hal pengambilan keputusan. Dimulai dari database terpusat yakni tempat mengakses dan meng-update oleh orang-orang memiliki tujuan tertentu dan wewenang tertentu. Data dan informasi sangat diperlukan di dalam suatu institusi. Hal ini sangat dibutuhkan karena data sangat berhubungan dengan sistem informasi karena dapat menyelaraskan visi dan isi dari suatu institusi atau universitas tersebut. Agar manajemen data dan informasi dapat di kembangkan dengan baik, maka di perlukan metode soft system methodology. Analisis soft system methodology pada dasarnya adalah sebuah metode sistematis yang digunakan untuk mengembangkan sistem informasi dengan menggunakan pendekatan yang terstruktur dengan mode konseptual dan mencapai tujuan dari perubahan yang diinginkan serta mengimplementasikannya. Dengan adanya metode analisis ini maka diharapkan akan dapat berguna dalam mengelola dan menyelesaikan masalah dalam bidang data dan informasi [1].

Soft system methodology pada awalnya muncul dikarenakan adanya sistem berpikir yang membentuk suatu kerangka berfikir konseptual. Pada cara berpikir ini artinya keseluruhan proses dari sistem akan dilihat dan dinilai merata tidak hanya pada bagian atau potret dari proses tersebut. Dalam system thinking ini terdapat yang dinamakan hard system thinking, sistem berpikir ini adalah teori berpikir umum yang mempunyai pengaruh dalam perkembangan sebuah sistem. Hal ini membuktikan bahwa suatu sistem teknologi terbukti berpengaruh terhadap kelangsungan jalannya suatu Lembaga dan sektor kehidupan manusia. Hal ini tentu sangat memudahkan dan membantu manusia dalam mengerjakan tugas atau 
kegiatan sehari-hari. Manajemen data dan informasi yang ada pada Lembaga Pendidikan umumnya berupa data-data mengenai sistem Pendidikan yang digunakan dalam Lembaga tersebut [3].

Terdapat beberapa alasan lain mengapa metode SSM digunakan dan dinilai tepat dalam membangun sistem informasi, berikut ini adalah alasan yang cukup beralasan: (1) Berpikir sistemik, didukung pengenalan karakteristik yang muncul dalam sistem dan kegiatan dilakukan secara bersama dalam monitoring dan controling. (2) Dalam aspek sosial dan organisasi pengembangan sistem informasi, diakui dalam bentuk arus budaya analisis, yang terus-menerus diperiksa dan diperbarui. (3) Proses teknis yang diperlukan untuk mengembangkan sistem dapat diwakili oleh Logic Streaming Analisis, meskipun tidak dengan proses aslinya. (4) Menawarkan proses pembelajaran in-built. (5) Diasumsikan adanya partisipasi semua stakeholder [4].

SSM adalah metodologi yang tepat karena metode SSM dapat menangkap kebutuhan pengguna dengan baik. SSM berkonsentrasi pada perspektif stakeholder dan dengan demikian memfasilitasi keterlibatan pengguna. Selain itu, alat yang digunakan (CATWOE dan Rich Picture) mudah untuk digunakan dan dipahami, hal ini memungkinkan partisipasi lanjutan dari kelompok pengguna. Jadi manfaat utama dari SSM adalah membuat keinginan untuk pindah dari masalah tidak terstruktur menjadi masalah terstruktur sesuai dengan perubahan yang diinginkan. Dengan menggunakan analisis CATWOE, membantu mengurangi situasi yang kompleks menjadi beberapa kunci yang relevan. Cara pandang sistemik sangat penting untuk menangani pemecahan masalah dalam organisasi. Seorang manajer tugas dasarnya adalah problem solver dan menghabiskan sebagian besar waktunya untuk berurusan dengan pertanyaanpertanyaan yang berkaitan dengan pemecahan masalah. Memiliki pandangan global terhadap masalah dalam organisasi dan berpikir strategis dan solutif, sangat penting untuk meningkatkan kemampuan pemecahan masalah organisasi di tingkat manajerial. Sehingga untuk menangani masalah perilaku manusia, diperlukan metodologi sistem lunak (SSM). Dalam studi kasus ini, metodologi SSM secara sistemik digunakan sebagai pedoman untuk diskusi tentang situasi dan masalah.[5] (Hananto \& Septianti, 2020)

\section{Tujuan penelitian}

Penelitian ini bertujuan untuk menginformasikan bagaimana pengembangan yang terjadi pada bidang manajemen data dan informasi menggunakan analisis Soft system methodology pada Universitas Advent Indonesia. Dalam hal ini penulis dituntut untuk dapat mengetahui teori dan juga menganalisis sistem tersebut dan menyimpulkan hasil dari observasi yang telah dibuat. Observasi dilakukan agar penulis dapat mengetahui dengan jelas dan nyata hasil dari penelitian yang dilakukan.

\section{Landasan Teori}

\section{State of The Art}

Penelitian ini didasari atas beberapa konsep penelitian terdahulu sebagai berikut:

Tabel 1 Penelitian Terdahulu

\begin{tabular}{|l|l|l|}
\hline No. & \multicolumn{1}{|c|}{ Judul Penelitian } & \multicolumn{1}{c|}{ Ringkasan } \\
\hline 1 & $\begin{array}{l}\text { Aplikasi Soft system methodology (SSM) } \\
\text { Untuk Perancangan Terintegrasi Biofull } \\
\text { Dalam Sektor Pertanian Dan Sektor Energi }\end{array}$ & $\begin{array}{l}\text { Pendekatan SSM yang diterapkan pada perencanaan } \\
\text { terintegrasi biofuel dalam sektor pertanian dan sektor energi } \\
\text { melalui tujuh tahap dalam SSM dengan mendefinisikan } \\
\text { CATWOE. Hasil penelitian ini mengungkapkan dari biodiesel } \\
\text { maupun bioethanol, keduanya memiliki potensi yang besar } \\
\text { untuk dipakai sebagai pengganti kebutuhan bahan bakar } \\
\text { minyak secara keseluruhan di Indonesia. }\end{array}$ \\
\hline 2 & $\begin{array}{l}\text { Pendekatan Soft system methodologyUntuk } \\
\text { Membangun Sebuah Sistem Informasi } \\
\text { Proyek Akhir menjelaskan bahwa } \\
\text { Membangun sebuah Sistem Informasi } \\
\text { Proyek Akhir (PA) }\end{array}$ & $\begin{array}{l}\text { Dalam membangun sebuah Sistem Informasi Proyek Akhir } \\
\text { (PA) yang akan menjadi salah satu upaya yang dapat } \\
\text { dalam proses pelaksanaan Proyek Akhir sejak daftar seminar } \\
\text { dampai dengan pelaksanaan sidang yang terjadi di }\end{array}$ \\
\hline
\end{tabular}




\begin{tabular}{|l|l|l|}
\hline & $\begin{array}{l}\text { Politeknik Telkom. Dengan menggunakan pendekatan Soft } \\
\text { Systems Methodology (SSM) dinilai mampu menjawab } \\
\text { tantangan dan permasalahan pada penelitian tersebut. }\end{array}$ \\
\hline
\end{tabular}

\section{Manajemen}

Manajemen diartikan sebagai sebuah proses karena di dalamnya terdapat beberapa kegiatan seperti pengorganisasian dan juga perencanaan. Manajemen merupakan sebuah proses yang dilakukan dengan menggunakan seluruh sumber daya yang ada secara efektif demi mencapai tujuan yang telah ditetapkan. Manajemen juga dianggap sebagai sebuah seni, karena dalam mengatur dan mengelola seluruh sumber daya yang ada membutuhkan seni agar dapat berfungsi dengan baik dalam mencapai tujuan [6]. Maka dari itu proses dari manajemen yang sudah saling berkaitan akan menjadi satu kesatuan yang tidak dapat dipisahkan [7]. Kesimpulannya adalah bahwa manajemen merupakan cara pengelolaan terhadap suatu organisasi agar organisasi tersebut dapat lebih terorganisir dengan baik. Manajemen data sangat diperlukan dalam sebuah organisasi atau Lembaga karena hal ini dapat membantu membuat kelangsungan jalannya organisasi dapat lebih terstruktur [4].

\section{Data}

Data pada hakikatnya adalah sebuah fakta atau bukti dari hasil penelitian yang dapat dijadikan sebagai suatu acuan dalam dasar kajian atau pendapat maupun dalam menyusun sebuah informasi. Dalam teknisnya, data merupakan satuan yang paling kecil yang berwujud angka, simbol, dan juga huruf dengan menggambarkan sebuah variabel tertentu berdasarkan data di lapangan. Data juga selalu berhubungan dengan suatu fakta yang memuat informasi waktu ataupun tempat serta segala sesuatu yang diyakini dan diketahui.

\section{Informasi}

Informasi merupakan suatu data yang dikumpulkan dalam satu kesatuan yang memiliki fakta mengenai sebuah peristiwa dan kemudian diolah menjadi sebuah data yang memiliki arti bagi penerima [8]. Maka pada kesimpulannya informasi adalah sebuah data atau rekaman peristiwa berdasarkan dengan fakta dan kemudian diolah menjadi sesuatu yang berguna dan memiliki arti bagi penerima dan juga pemakai informasi.

\section{Metode Penelitian}

\section{Populasi dan Sampel}

Menurut Warsito, populasi merupakan suatu keseluruhan objek penelitian yang terdiri dari manusia, hewan, tumbuhan, gejala, maupun peristiwa, sebagai suatu sumber data yang mempunyai karakteristik pada sebuah penelitian. Sampel adalah bagian dari jumlah atau karakteristik tertentu yang diambil dari populasi yang nantinya akan diteliti oleh panelis secara detail/rinci. Berdasarkan data dari BPS (Badan Pusat Statistik) terdapat lebih dari 7,5 juta mahasiswa yang ada di Indonesia, maka dari banyaknya populasi tersebut akan diambil sampel dari hasil wawancara dengan Kepala BAA di Universitas Advent Indonesia, serta 5 mahasiswa aktif Universitas Advent Indonesia dengan rentang usia 20-25 tahun sebagai subjek penelitian.

\section{Jenis Penelitian}

Penelitian kualitatif mempunyai ciri-ciri atau sebuah karakteristik tertentu di dalamnya yang menjadi pembeda antara penelitian satu dan lainnya. Menjelaskan karakteristik dalam penelitian kualitatif adalah sebagai berikut: latar ilmiah, manusia sebagai alat, analisis data secara induktif, teori dari dasar, deskriptif dan lebih mementingkan proses dari pada hasil. Penelitian deskriptif merupakan suatu bentuk dalam penelitian yang mempunyai tujuan untuk dapat mendeskripsikan penyelesaian dari sebuah masalah yang ada berdasar kepada banyaknya data yang dikumpulkan. 


\section{Metode Pengumpulan Data}

Metode merupakan suatu cara ilmiah yang dilakukan pada penelitian untuk mendapatkan sumber data dan tujuan tertentu dalam suatu penelitian [9]. Pada hakikatnya metode adalah bagaimana cara peneliti mengelola dan mengolah data dengan Teknik pengumpulan data yang telah ditentukan.

1. Wawancara

Wawancara atau interview adalah suatu bentuk teknik pengumpulan data dengan tujuan mendapatkan solusi pada masalah yang diteliti serta bentuk komunikasi langsung dengan responden. Wawancara yaitu berupa sesi tanya-jawab yang terjadi antara peneliti dengan responden. Metode ini dilakukan agar peneliti dapat melakukan penelitian secara mendalam dan mendapatkan sumber data yang valid langsung dari responden. Dengan adanya wawancara, maka peneliti akan dapat mengetahui hal-hal yang lebih mendalam tentang partisipan dalam menginterpretasikan situasi dan fenomena yang terjadi, dimana hal ini tidak dapat ditemukan melalui observasi.[10] (Sugiyono, 2016)

2. Observasi

observasi adalah suatu proses yang didahului dengan pengamatan kemudian pencatatan yang bersifat sistematis, logis, objektif, dan rasional terhadap berbagai macam fenomena dalam situasi yang sebenarnya, maupun situasi buatan [11]. Pengambilan informasi dengan observasi dilakukan pada bagian administrasi dan informasi pada Universitas Advent Indonesia.

\section{Bentuk Dasar Soft system methodology}

Pengalaman yang dialami oleh manusia baik yang individu maupun publik umumnya digunakan untuk dapat melakukan suatu tindakan tertentu. Beberapa tindakan tersebut biasanya memiliki arah tersendiri yang nantinya akan menghasilkan sebuah pengalaman baru dari pengetahuan yang telah diperoleh.[5] (Hananto \& Septianti, 2020)

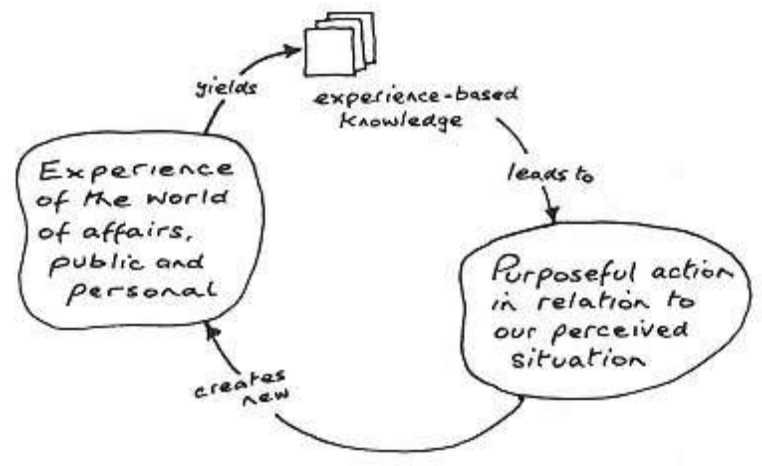

Gambar 1 Siklus Pengalaman-Aksi

Berbeda dengan pengalaman-aksi, bentuk dari soft system methodology yakni berupa hasil perbandingan antara sebuah situasi nyata dan sistem yang relevan dengan aktivitas yang dilakukan untuk mencapai suatu tujuan tertentu. Pada proses di atas maka kita dapat melihat pengalaman menjadi kunci penting dalam melakukan sebuah aksi. Kemudian pengalaman tersebut membawa kepada tujuan yang ditetapkan untuk dapat mencapai situasi tertentu. Selanjutnya bergerak lagi kepada pengalaman baru yang dimana sudah lebih banyak hal yang didapat dan dialami baik dalam bentuk individu maupun publik.

Persepsi akan pengalaman yang dapat membentuk aksi ini akhirnya menciptakan sebuah sistem dimana dalam hal penyelesaian permasalahan kita selalu mengidentifikasi dan menilainya berdasarkan pengalaman yang telah dialami yang dijadikan tolak ukur dalam sebuah solusi. Pengalaman-pengalaman ini memang sangat berguna dalam pemecahan masalah karena dengan begitu kita dapat lebih memahami dan mengerti ketika masalah tersebut terulang Kembali.

Untuk dapat memunculkan aksi maka sebagai manusia yang mempunyai akal dan pikiran maka akan berpikir terhadap resiko dan juga analisis terhadap pengalaman sebelumnya dalam melakukan aksi 
tersebut. Siklus di atas menggambarkan proses manusia dalam melakukan sebuah aksi berdasar kepada pengalaman yang kemudian hal tersebut menciptakan pengalaman baru baik yang bersifat individu/publik dan memiliki suatu tujuan tertentu untuk mewujudkan situasi tertentu.

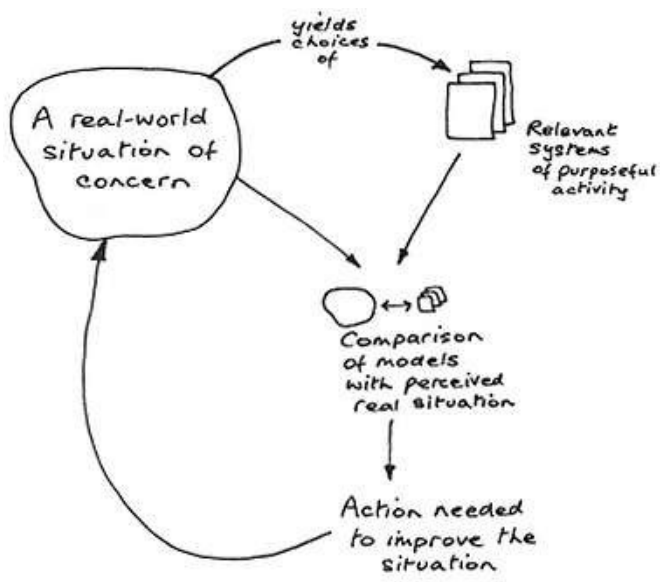

Gambar 2 Bentuk Dasar SSM

Berdasarkan pada Gambar 2. Di atas maka kita dapat melihat bentuk dasar pada soft system methodology (SSM) yang mempunyai proses tersendiri. Hasil yang didapatkan dari perbandingan kedua model tersebut nantinya akan menghasilkan sejumlah tindakan dalam pemodelan yang lebih baik lagi. Kegagalan yang terjadi pada system engineering karena pemecahan masalah yang tidak terstruktur membuat organisasi terus berpikir untuk menggunakan pendekatan lain yang dinilai lebih fleksibel dalam menghadapi situasi nyata. Soft sytem methodology merupakan sebuah implementasi system thinking pada Human Activity Systems. Dalam melakukan analisa terhadap soft system, baik pada masalah-masalah sosial ataupun seperti humaniora (politik, budaya, tata-nilai, estetika, dsb) yang merupakan faktor-faktor penting untuk diikutsertakan dan juga diperhatikan dalam analisis (Behavioral Approaches).

\section{Proses Soft System Methodologhy}

Dalam proses ini, Soft system methodology (SSM) merupakan pembaruan dari Hard System Methodology (HSM), merupakan metodologi sistem dimana jumlah variabel dibatasi seminimal mungkin untuk menyederhanakan masalah dan menyederhanakan perumusan solusi. Adanya pembaruan dan perubahan sistem ini dikarenakan adanya kelemahan HSM yang tidak sesuai untuk masalah organisasi. Hal ini terjadi karena rumus sistem HSM hanya dapat menjawab solusi masalah pada saat itu, kemudian ketika solusi tersebut digunakan pada waktu yang berbeda dan variabel dalam domain tersebut berubah maka solusi tersebut tidak berlaku lagi. Berbeda dengan metode HSM yang sangat terbatas pada formulanya, metode SSM tidak membatasi permasalahan yang ada dan juga mencoba untuk mengidentifikasi sebanyakbanyaknya variabel yang berinteraksi pada sistem tersebut. Maka pendefinisian tentang solusi dari permasalahan akan lebih kompleks dan lengkap dikarenakan banyak aspek yang menjadi pertimbangan dari hasil identifikasi dan mampu dalam mengatasi perubahan yang mungkin terjadi pada suatu organisasi.

Analisis sistematis yang dilakukan dalam proses ini akan dapat mengidentifikasi faktor-faktor yang menyebabkan lembaga berfungsi atau tidak berfungsi dalam organisasi yang bertanggung jawab untuk revitalisasi dan dalam metode alternatif penyelesaian masalah. Dengan mengadopsi mekanisme sistematis yang bertujuan untuk menghindari ketidakseimbangan kelembagaan dengan menghilangkan struktur dan mekanisme, dengan menggunakan ide-ide sistem yang diusulkan oleh Metcalfe [12]. Dalam hal tersebut disimpulkan bahwa pekerjaan secara keseluruhan, melalui pekerjaan secara keseluruhan, digunakan pekerjaan lama yang kaku dan kaku serta memberdayakan institusi baru. Untuk memecahkan masalah baru, seseorang juga harus belajar membuat sistem untuk melakukannya, dan membuang struktur dan mekanisme yang tumbuh di sekitar masalah. Tidak hanya perlu memecahkan serangkaian masalah baru, tetapi bahkan meninggalkan jejak organisasi dari bentuk-bentuk khusus yang rumit dari kegiatan pemerintah yang saat ini sedang berlangsung. 
SSM diperkenalkan pada tahun 1981 dan dikembangkan hingga tahun 1990 [5]. Selama periode ini SSM telah banyak mengalami revisi dan modifikasi, namun model yang paling umum digunakan masih model asli yang terdiri dari tujuh tahap. Terdapat tujuh tahapan pada metode SSM yaitu sebagai berikut:

1. Deskripsi Masalah Sistem akan mendeskripsikan masalah secara detail pada tahap pertama dan menjelaskan masalah secara detail.

2. Mendeskripsikan situasi masalah dalam bentuk gambar (rich picture) yang berisi penjelasan bagaimana masalah itu terjadi, kemudian dicari solusinya.

3. Definisikan kata kunci (definisi root), yaitu mengumpulkan kata kunci yang harus ditentukan dalam jalur proses bisnis dengan teks yang ringkas. Dari definisi root ini memetakannya ke elemen CATWOE- (klien, aktor, transformasi, pandangan dunia, pemilik, lingkungan).

4. Membuat model dengan berdasarkan root definitions

5. Bandingkan dengan model aslinya

6. Lakukan perubahan atau penyesuaian model

7. Perbaiki sistem yang diusulkan untuk menyelesaikan masalah dengan cepat

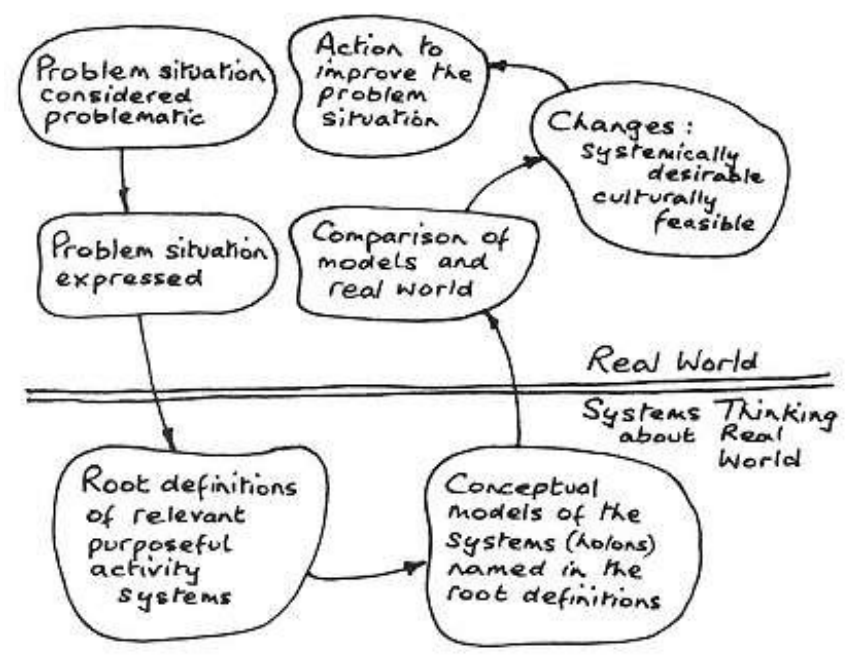

Gambar 3 Proses SSM

Dalam menggunakan SSM sebagai penyelesaian permasalahan maka dapat dilihat dari Gambar 3. Dari ketujuh tahapan proses pada SSM kita dapat melihat bagaimana SSM dapat terjadi. Ketujuh tahapan tersebut tentu memiliki fungsi dan tujuan yang penting dalam terjadinya proses SSM. SSM adalah cara yang berguna untuk menangkap kebutuhan pengguna.

SSM berfokus pada pandangan pemangku kepentingan, sehingga memfasilitasi partisipasi pengguna. Selain itu, alat yang digunakan (CATWOE dan Rich Picture) mudah digunakan dan dipahami, yang memungkinkan partisipasi berkelanjutan dari kelompok pengguna. Oleh karena itu, manfaat utama SSM adalah bahwa orang dapat beralih dari masalah tidak terstruktur ke masalah terstruktur berdasarkan perubahan yang diperlukan. Dengan menggunakan analisis CATWOE, ini membantu mengurangi kompleksitas ke banyak kunci terkait. Perspektif sistematis sangat penting untuk menangani masalah dalam organisasi. Manajer tugas pada dasarnya adalah pemecah masalah dan menghabiskan sebagian besar waktunya menangani masalah yang berkaitan dengan pemecahan masalah. Pemahaman yang komprehensif tentang masalah dalam organisasi serta pemikiran dan solusi strategis sangat penting untuk meningkatkan kemampuan manajemen dalam menyelesaikan masalah dalam organisasi. Oleh karena itu, untuk mengatasi masalah perilaku manusia diperlukan pendekatan soft system.

\section{Rich Picture}

Rich picture adalah sebuah langkah di dalam SSM yang cara kerjanya adalah dengan mengeksplorasi, 
mengakui dan juga mengidentifikasikan suatu situasi serta mengekspresikannya melalui sebuah diagram untuk membuat sebuah model awal. Diagram yang dibuat ini nantinya akan sangat membantu dalam proses Analisa luas yang dilakukan peneliti pada suatu kondisi tertentu [4].

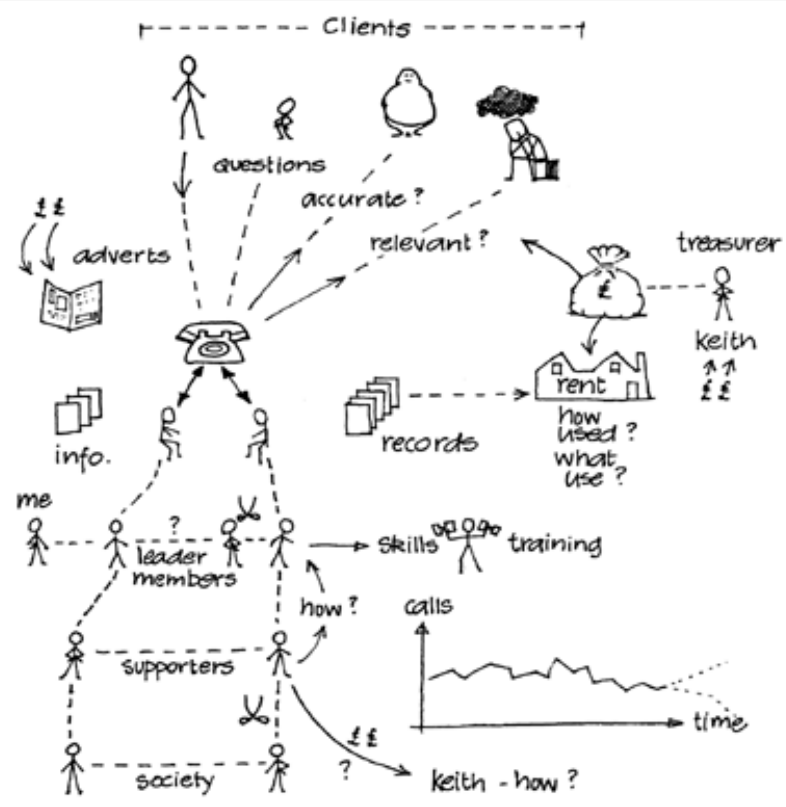

Gambar 4 Contoh Rich Picture

Rich Picture juga di rancang agar Soft system methodology dapat berjalan lebih efektif dan juga efisien serta dapat mengidentifikasikan masalah dan menganalisa sesuatu yang tidak terorganisir dengan baik melalui diagram dengan beberapa aturan, di antaranya:

- Menggunakan Simbol untuk mempresentasikan situasi

- Meminimalkan penggunaan kata-kata

- Hubungkan setiap gambar dengan sebab dan akibat

- Tidak menerapkan sebuah struktur

\section{Catwoe}

CATWOE, ini adalah C untuk customer/pelanggan (pihak yang mendapat keuntungan atau kerugian karena konversi), "aktor" (pihak yang melakukan konversi), "konversi" (perubahan dari masukan ke keluaran), "pandangan dunia "(sudut pandang), dan" pemilik "(Siapa yang berpartisipasi dalam partai) akronim dapat mencegah aktivitas perubahan), kendala lingkungan (hambatan lingkungan). Selain itu, evaluasi kinerja dilakukan melalui "efisiensi", "efisiensi" dan "efektivitas" (3E). Oleh karena itu, dapat disimpulkan bahwa CATWOE dapat dijadikan pertimbangan dalam pengelolaan data dan informasi dalam menciptakan inovasi [13].

\section{Hasil}

Implementasi dalam soft system methodology ini dilakukan dengan tujuan untuk dapat mengetahui pengembangan manajemen data dan informasi pada Universitas Advent Indonesia. Manajemen data dan informasi pada Universitas Advent dinilai mengalami hambatan maka dari itu metode SSM dinilai sebagai metode yang paling cocok dengan permasalahan ini.

\section{Step 1: Deskripsi Situasi Permasalahan}

Informasi merupakan suatu hal yang penting dalam kehidupan sehari-hari terutama pada lingkup 
kampus atau universitas. Semua hal terkait informasi pendaftaran, informasi jadwal kuliah, serta hal-hal lainnya sangat penting bagi warga kampus terutama kepada mahasiswa yang tinggal di asrama. Maka dari itu ketepatan dan kebenaran dalam informasi haruslah akurat karena jika terjadi kesalahan dalam memberikan informasi maka akan terjadinya miss information dimana informasi yang diberikan tidak sesuai.

Selain itu, sistem manual yang digunakan dalam proses pendaftaran perkuliahan juga mengakibatkan menumpuknya berkas pendaftaran yang ada di unit administrasi jurusan. Hal tersebut juga terjadi pada proses penjadwalan yang bersifat manual dan sering mengakibatkan mahasiswa menunggu cukup lama untuk mendapatkan jadwal sidang, selain itu pemilihan waktu yang dinilai tidak konsisten karena banyaknya pemindahan jadwal akibat jadwal yang bentrok baik dosen penguji ataupun dosen pembimbing. Serta adanya perbedaan informasi yang diberikan melalui biro akademik dengan website kampus. Hal ini tentu menyebabkan keresahan tersendiri bagi para mahasiswa terutama yang tinggal pada asrama karena lebih banyak terpapar informasi.

\section{Step 2: Rich Picture}

Rich picture merupakan sebuah langkah di dalam SSM yang cara kerjanya adalah dengan mengeksplorasi, mengakui dan juga mengidentifikasikan suatu situasi serta mengekspresikannya melalui sebuah diagram untuk membuat sebuah model awal. Diagram yang dibuat ini nantinya akan sangat membantu dalam proses Analisa luas yang dilakukan peneliti pada suatu kondisi tertentu. Di bawah ini merupakan bentuk rich picture dari penelitian ini:

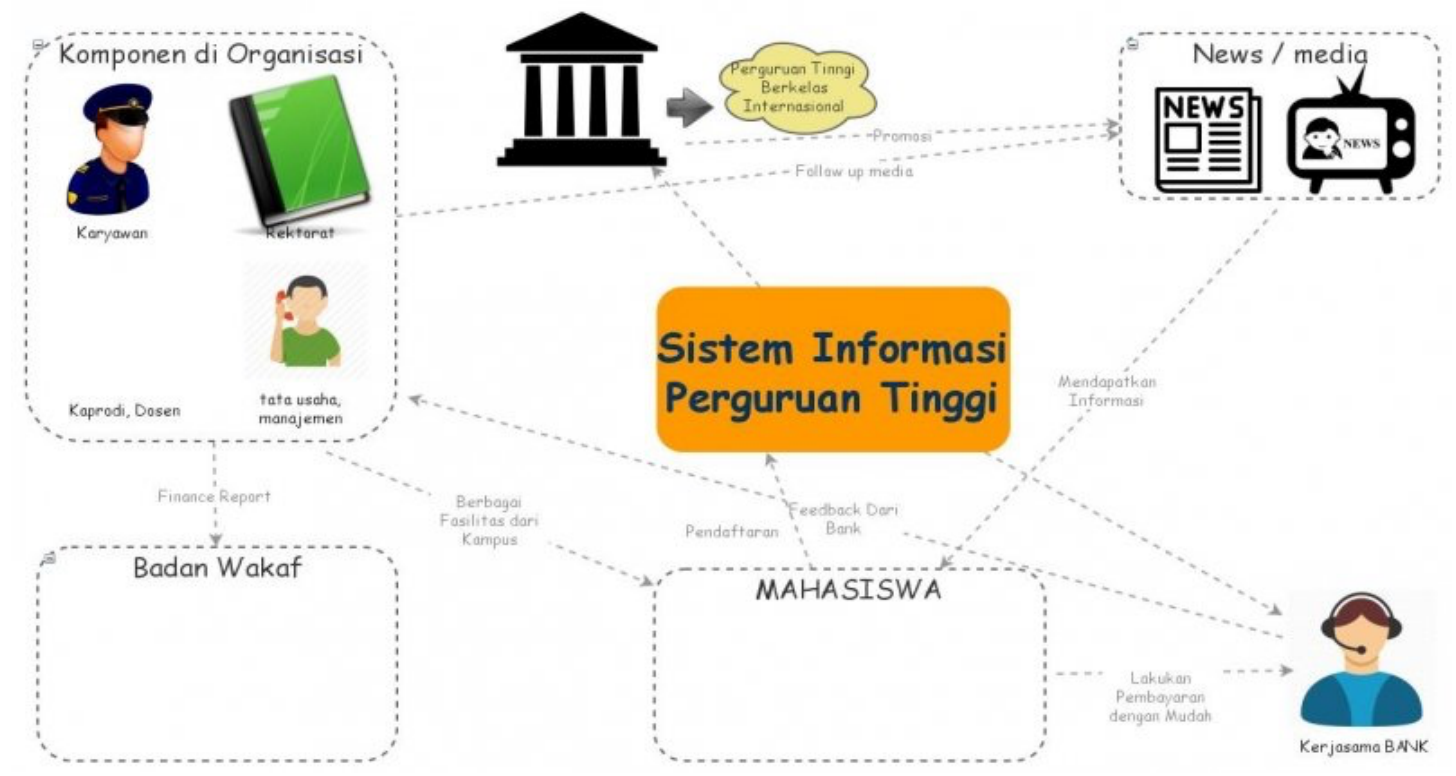

Gambar 5 Rich Picture

\section{Step 3: Root Definition}

Bentuk dari 'root definition' adalah: $A$ system to do $X$, by (means of) $Y$ in order to do $Z$. Dengan $X, Y$, Z sebagai berikut:

- X: Apa yang dilakukan oleh sistem

- Y: Bagaimana cara sistem mengerjakan

- Z: Mengapa hal tersebut harus dikerjakan

Dari bentuk tersebut maka dirumuskan 'root definition' sebagai berikut: bagian biro akademik dapat mengajukan pembuatan sistem Informasi yang terintegrasi dan terstruktur dengan tepat menggunakan sistem informasi yang digunakan pada website UNAI untuk dapat melakukan proses pendaftaran, penjadwalan, dan peng-input-an nilai hasil dari seminar, sidang, maupun pada sistem perkuliahan. Sistem 
Informasi tersebut nantinya akan dikerjakan oleh unit sistem informasi atau diproyekan kepada mahasiswa untuk menjadi topik sehingga pada tahun berikutnya dapat digunakan (Y). Sistem Informasi ini dibuat dengan tujuan agar proses pendaftaran pada perkuliahan maupun sidang akan semakin efektif dan juga efisien serta mengurangi jumlah berkas yang ada di administrasi jurusan karena akan menggunakan database yang dapat diakses oleh staff admin jurusan dan koordinator dari masing-masing Prodi (Z).

Tabel 2 Elemen CATWOE

\begin{tabular}{|c|c|}
\hline $\begin{array}{l}\text { Elemen } \\
\text { CATWOE }\end{array}$ & Deskripsi \\
\hline Customers & Mahasiswa dan Kepala BAA \\
\hline Actors & Administrasi Jurusan dan Koordinator \\
\hline Transformation & $\begin{array}{c}\text { Proses pendaftaran, penjadwalan dan penginputan nilai perkuliahan yang pada } \\
\text { awalnya dilakukan secara manual serta pemberian informasi yang tidak sesuai } \\
\text { dengan yang ada di web menjadi suatu sistem Informasi yang mampu untuk } \\
\text { mengotomatisasi seluruh aktivitas yang terkait dengan pendaftaran perkuliahan } \\
\text { maupun sidang }\end{array}$ \\
\hline Worldview & $\begin{array}{l}\text { Mempermudah dan mempercepat proses pendaftaran, rekapitulasi, dan } \\
\text { penjadwalan sidang serta penyampaian informasi yang tepat sesuai dengan } \\
\text { yang tertera di pada website kampus maupun pada biro akademik }\end{array}$ \\
\hline Owners & Kepala BAA \\
\hline $\begin{array}{l}\text { Enviromental } \\
\text { Contraints }\end{array}$ & $\begin{array}{c}\text { Prosedur pendaftaran seminar yang bersifat manual dan IT infrastructure } \\
\text { yang kurang memadai pada universitas }\end{array}$ \\
\hline
\end{tabular}

\section{Step 4: Model konseptual dari "Root Definitions"}

Tabel 3 Elemen 3E

\begin{tabular}{|c|c|}
\hline $\begin{array}{c}\text { Ukuran } \\
\text { Performansi }\end{array}$ & Keterangan \\
\hline Efficacy & $\begin{array}{r}\text { Apakah penggunaan sistem informasi SSM nantinya dapat mengurangi kesalahan- } \\
\text { kesalahan yang sering terjadi pada saat penjadwalan maupun dalam } \\
\text { penyampaian informasi? }\end{array}$ \\
\hline Efficiency & $\begin{array}{c}\text { Apakah dengan penggunaan sistem informasi SSM dapat mempercepat dalam } \\
\text { proses pendaftaran, rekapitulasi, dan penyampaian informasi? }\end{array}$ \\
\hline Effectiveness & $\begin{array}{c}\text { Apakah dengan penggunaan sistem informasi SSM merupakan solusi yang } \\
\text { tepat untuk dapat mengatasi permasalahan yang terjadi dalam proses } \\
\text { pendaftaran, rekapitulasi, dan penyampaian informasi? }\end{array}$ \\
\hline
\end{tabular}

Berdasarkan hasil dari tahapan-tahapan yang dilakukan sebelumnya dengan permasalahan yang muncul maka dibuatlah sebuah sistem informasi pada setiap Prodi yang dapat diakses oleh setiap actor yang terlibat dalam proses tersebut. Model konseptual data warehouse atau model dimensional adalah desain logis yang merepresentasikan data dalam bentuk standar dan mendukung akses cepat ke data. Ada beberapa istilah yang terkait dengan model ini, yaitu tabel fakta, tabel dimensi, dan hierarki. Dengan demikian, dapat dikatakan bahwa model konseptual adalah suatu gambaran yang menyajikan data dan mendukung akses cepat ke data tersebut.

\section{Step 5: Perbandingan Antara Model dan Dunia Nyata}

Bandingkan model dengan keadaan sebenarnya (perbandingan antara model dengan dunia nyata), yaitu perbandingan antara sketsa situasi nyata dengan model yang dibuat sehingga Anda dapat melihat bidang-bidang yang perlu diperbaiki dan aspek-aspek yang penting. Hal tersebut akan digunakan sebagai pembanding untuk perubahan sistem [14]. 
Tabel 4 Perbandingan Model Dan Dunia Nyata

\begin{tabular}{|c|c|c|}
\hline Activity & $\begin{array}{c}\text { Is it done in the real } \\
\text { situation? } \\
\text { How is it done? }\end{array}$ & $\begin{array}{c}\text { Comments } \\
\text { Recommendation }\end{array}$ \\
\hline $\begin{array}{c}\text { Mahasiswa melakukan pendaftaran } \\
\text { secara online }\end{array}$ & $\begin{array}{c}\text { Beberapa mahasiswa masih tidak } \\
\text { memahami cara kerja sistem } \\
\text { informasi berbasis SSM }\end{array}$ & $\begin{array}{c}\text { Diperlukan adanya user } \\
\text { manual dan sosialisasi }\end{array}$ \\
\hline $\begin{array}{c}\text { Staf administrasi jurusan dapat } \\
\text { melakukan proses validasi pendaftaran } \\
\text { secara online }\end{array}$ & $\begin{array}{c}\text { Proses sudah berjalan lancar } \\
\text { Koordinator dan Kepala BAA } \\
\text { melakukan proses penjadwalan } \\
\text { dengan metode baru }\end{array}$ & Sudah mulai diperbaiki \\
\hline $\begin{array}{c}\text { Integrasi Sistem Informasi SSM } \\
\text { Penyampaian informasi pada biro } \\
\text { akademik dan website UNAI }\end{array}$ & $\begin{array}{c}\text { Perlu diadakannya } \\
\text { sosialisasi menyeluruh } \\
\text { kepada mahasiswa dan } \\
\text { pengurus }\end{array}$ \\
\hline $\begin{array}{c}\text { Rekapitulasi nilai dan data mahasiswa } \\
\text { N/A }\end{array}$ & $\begin{array}{c}\text { Masih terjadinya kendala tetapi } \\
\text { hal tersebut sedang berusaha } \\
\text { ditangani oleh pihak pengurus } \\
\text { terkait }\end{array}$ & $\begin{array}{c}\text { Perlu diadakannya } \\
\text { perbaikan pada Sistem } \\
\text { Informasi yang sedang } \\
\text { berjalan }\end{array}$ \\
\hline
\end{tabular}

\section{Step 6 \& 7: Perubahan yang akan dilakukan serta aksi untuk perbaikan pada situasi}

Melakukan sebuah perbaikan yang telah direkomendasikan (action to improve the problem situation) serta mengimplementasikannya ke dalam situasi nyata dengan beberapa perbandingan dalam aspek permasalahan. fase akhir adalah melakukan rekomendasi-rekomendasi perbaikan terhadap sistem lama.

Tabel 5 Perbaikan Situasi

\begin{tabular}{|l|l|}
\hline \multicolumn{1}{|c|}{$\begin{array}{c}\text { Usulan Perubahan yang } \\
\text { dapat dilakukan }\end{array}$} & \multicolumn{1}{|c|}{ Aksi dalam Perbaikan Situasi } \\
\hline $\begin{array}{l}\text { Sosialisasi kepada mahasiswa dan } \\
\text { dosen serta pengurus biro akademik } \\
\text { dalam penggunaan sistem informasi } \\
\text { SSM }\end{array}$ & $\begin{array}{l}\text { Melakukan penjadwalan untuk sosialisasi setelah proses } \\
\text { pembuatan pada sistem Informasi selesai dan demo yang } \\
\text { dilakukan oleh unit kepada pengurus berjalan baik }\end{array}$ \\
\hline $\begin{array}{l}\text { Training penggunaan Sistem } \\
\text { Informasi SSM pada staf admin dan } \\
\text { koordinator }\end{array}$ & $\begin{array}{l}\text { Melaksanakan beberapa sesi training dan juga percobaan } \\
\text { penyampaian informasi kepada mahasiswa yang dalam prosesnya } \\
\text { menggunakan metode SSM }\end{array}$ \\
\hline $\begin{array}{l}\text { Perlu diadakannya monitoring } \\
\text { sampai proses berjalan stabil }\end{array}$ & $\begin{array}{l}\text { Perlu adanya review hasil proses bulanan beberapa kali dengan } \\
\text { koordinator dan Kepala BAA }\end{array}$ \\
\hline
\end{tabular}

\section{Kesimpulan}

Berdasarkan hasil penelitian di atas, dapat disimpulkan bahwa penggunaan metodologi soft system dalam pengelolaan data dan informasi merupakan salah satu metode alternatif yang tepat dalam menyelesaikan tantangan dan permasalahan yang dihadapi oleh mahasiswa Universitas Advent Indonesia untuk memudahkan pendaftaran dan transfer informasi di asrama. Metode SSM juga memiliki pengaruh yang besar dalam membuat sistem informasi yang lebih terstruktur di Universitas Advent Indonesia. Untuk menggunakan SSM secara efektif, pertama-tama kita harus mengidentifikasi masalah yang muncul, dan kemudian membaginya menjadi tujuh langkah SSM. Soft system methodology (SSM) merupakan pembaruan dari Hard System Methodology (HSM), merupakan metodologi sistem dimana jumlah variabel dibatasi seminimal mungkin untuk menyederhanakan masalah dan menyederhanakan perumusan solusi. 
SSM juga memiliki nilai tinggi yang melekat dalam penelitian dan meningkatkan aktivitas rekayasa persyaratan yang berpusat pada pengguna [15].

SSM dalam analisis di atas juga terindikasi Mempermudah dan mempercepat proses pendaftaran, rekapitulasi, dan penjadwalan sidang serta penyampaian informasi yang tepat sesuai dengan yang tertera di pada website kampus maupun pada biro akademik, Melakukan penjadwalan untuk sosialisasi setelah proses pembuatan pada sistem Informasi selesai dan demo yang dilakukan oleh unit kepada pengurus berjalan baik, kemudian melaksanakan beberapa sesi training dan juga percobaan penyampaian informasi kepada mahasiswa. Serta perbandingan model dan pada situasi asli memiliki beberapa aspek yang sama dan dapat dijadikan pertimbangan bagi pengurus biro akademik. Serta, diperlukan adanya review hasil proses bulanan beberapa kali dengan koordinator dan Kepala BAA. Dari hasil penelitian tersebut maka diharapkan penggunaan metode SSM ini dapat membantu pemecahan masalah pada Universitas Advent Indonesia agar jadi lebih baik lagi, sehingga dapat beradaptasi dengan berbagai sudut pandang yang muncul di lingkungan saat ini. Unsur yang sangat penting dalam membangun sistem informasi dengan teknik CATWOE adalah kreativitas. Dengan kreativitas akan meningkatkan kemampuan untuk merespon secara adaptif atas kebutuhan untuk menyelesaikan masalah dan menentukan peta permasalahan yang ada dan proses dengan teknik CATWOE dapat dilakukan secara iteratif hingga menemukan root definition yang paling tepat [3].

\section{Referensi}

[1] D. Rahdiyantha, "Revitalisasi Pembelajaran Sebagai Upaya Peningkatan Mutu Pendidikan Vokasional," Seminar Nasional Pendidikan Vokasional, 2017.

[2] Yanto and B. Ngaliman, Ergonomi Dasar-dasar Studi Waktu dan Gerakan untuk Analisis dan perbaikan Sistem Kerja, Jakarta: Andi, 2017.

[3] H. Rasminto, F. D. Silalahi and B. Hartono, "Analisis Kebutuhan E-Learning Untuk Pengembangan Mutu KBM Dengan Soft system methodology Pada SMK di Semarang," vol. 13, pp. 138-149, 2020.

[4] M. Sumadyo, "PENGGUNAAN TEKNIK ANALISIS DALAM PENGEMBANGAN SISTEM INFORMASI," Jurnal Penelitian IImu Komputer, pp. 36 -48, 2016.

[5] A. Hananto and W. Septianti, "Pendekatan Soft system methodology Untuk Perancangan Model Pembelajaran Praktik Berbasis Produksi," Jurnal Teknik Industri, vol. 10, pp. 1-13, 2020.

[6] N. A. Atikasari, "IMPLEMENTASI MANAJEMEN BERBASIS SEKOLAH UNTUK," Jurnal Bahana Manajemen Pendidikan, pp. 1-7, 2020.

[7] S. Batlajery, "Analisis Manajemen Control dalam Meningkatkan Efektivitas Kinerja Aparatur Pemerintahan Kampung Tambat Kabupaten Merauke," Jurnal IImu Ekonomi \& Sosial, vol. 7, pp. 6178, 2016.

[8] E. Y. Anggraeni and R. Irviani, Pengantar Sistem Informasi, Yogyakarta: Andi, 2017.

[9] Sugiyono, Metode Penelitian Kuantitatif, Bandung: Alfabeta, 2018.

[10] Sugiyono, Metode Penelitian Kuantitatif, Kualitatif dan R\&D, Bandung: Alfabeta, 2016.

[11] K. Andi, Perancangan Sistem Informasi dan Aplikasinya, Yogyakarta: Gava Media, 2018.

[12] Metcalfe, "Tectonic evolution of Sundaland," Bulletin of the Geological Society of Malaysia, vol. 63, pp. 27-60, 2017.

[13] H. Lukiswara, "Analisis Perencanaan Pembangunan Daerah Dengan Pendekatan Sistem Lunak di Kabupaten Trenggalek," Jurnal IImiah Administrasi Publik (JIAP), pp. 216-226, 2016.

[14] R. Adisetiawan, "FAKTOR YANG MEMPENGARUHI LULUSAN SMA DALAM MEMILIH FAKULTAS EKONOMI PROGRAM STUDI MANAJEMEN," Jurnal Ilmiah Universitas Batanghari Jambi Vol.16 No.3, pp. 1-10, 2016. 
[15] I. Lewenusa, "REKAYASA KEBUTUHAN PERANGKAT LUNAK PADA PERUSAHAAN SKALA KECIL DAN MENENGAH DENGAN PENDEKATAN SOFT SYSTEM METHODOLOGY (SSM)," Journal of Computer Science and Information Systems, vol. 1, pp. 49-57, 2017. 